\title{
Sistem Rekomendasi Menu Harian Makanan Pendamping Air Susu Ibu (MPASI) Berdasarkan Kebutuhan Kalori Bayi dengan Metode TOPSIS
}

\author{
Recommender System of Daily Menu of Complementary Breastfeeding Based \\ on Caloric Needs with TOPSIS Method
}

\author{
SARI WIDYA SIHWI*, HESTIN MULYASARI, RISTU SAPTONO, BUDIANTI \\ WIBOWORINI
}

\begin{abstract}
Abstrak
Pada bayi usia enam sampai dengan dua puluh empat bulan, makanan pendamping ASI (MPASI) harus mulai diberikan. MPASI harus bersifat mencukupi untuk bayi untuk memenuhi kebutuhan nutrisi bagi pertumbuhan bayi dengan masih memperhatikan keberlangsungan pemberian ASI. Dalam pemenuhan kebutuhan nutrisi, jumlah kalori merupakan salah satu faktor yang perlu diperhatikan. Jika setiap kali ibu akan mempersiapkan makanan untuk bayinya harus mempertimbangkan pemenuhan kalori tersebut maka akan sangat tidak efisien waktu dan tenaga. Untuk itu, penelitian ini mengusulkan dibangunnya sebuah sistem rekomendasi menu harian bayi dengan mempertimbangkan kebutuhan kalori harian bayi dengan menggunakan metode technique for order preference by similarity to ideal solution (TOPSIS). Tahapan yang dilakukan dalam penelitian ini adalah pengumpulan data, analisa penerapan metode, implementasi, dan pengujian. Dalam penelitian ini, berhasil dibangun sistem rekomendasi yang diinginkan, yaitu menghasilkan menu harian dengan jumlah waktu makan sesuai usia bayi dengan memperhatikan nutrisi dan preferensi user terhadap bahan makanan yang digunakan. Hasil pengujian menunjukkan fungsi-fungsi yang ada dalam sistem rekomendasi ini telah sesuai dengan yang diharapkan.
\end{abstract}

Kata Kunci: bayi, kalori, kebutuhan nutrisi harian, MPASI, sistem rekomendasi, TOPSIS

\begin{abstract}
In infants aged six to twelve months, the complementary breastfeeding should be given. The complementary breastfeeding will be sufficient for the infant to meet the nutritional needs while maintaining the breastfeeding. In the fulfillment of the nutritional needs, the number of calories is one factor to be considered. If every time the mother would prepare food for her infant must consider the fulfillment of those calories, it will be very inefficient in time and energy. Because of that reason, this study proposes the construction of an infants daily menu recommendation system, which is taking into account the daily caloric needsof the infant by using technique for order preference by similarity to ideal solution(TOPSIS). Steps being taken in this study is the data collection, analysis of methods implementation, implementation and testing. In this study, it has succeed in buiding the desired system which gives a recommendation in the form of daily menu which has the appropriate feeding number based on age by taking into account the daily nutritional need and the user preference towards the food ingredients. The testing results show all the functions in this system has already been complies with the expected functions.
\end{abstract}

Keywords: calories, complementary breastfeeding, daily nutritional need, infant, recommender system, TOPSIS

\section{PENDAHULUAN}

Pada bayi usia enam sampai dua puluh empat bulan, air susu ibu (ASI) sudah tidak dapat memenuhi kebutuhan nutrisi tunggal bayi. Oleh karena itulah, bayi perlu diberikan

\footnotetext{
Jurusan Ilmu Komputer, Fakultas Matematika dan Ilmu Pengetahuan Alam, Universitas Sebelas Maret, Surakarta

*Lab Gizi, Fakultas Kedokteran, Universitas Sebelas Maret, Surakarta

*Penulis Korespondensi, telp: 0271-663451, email: sari.widya.sihwi@gmail.com
} 
makanan pendamping ASI (MPASI), yaitu yang mencakup seluruh makanan padat dan cair selain air susu ibu atau susu formula (Agostoni et al. 2008), untuk memenuhi kebutuhan nutrisinya. Perpindahan dari pemberian ASI eksklusif ke MPASI biasanya mencakup periode usia enam bulan hingga delapan belas sampai dua puluh empat bulan. Periode tersebut merupakan periode rentan malnutrisi pada banyak bayi. World Health Organization (WHO) memperkirakan 2 dari 5 anak tidak tumbuh dengan baik pada negara-negara dengan penghasilan rendah (WHO 2014). Oleh karena itulah maka pemberian MPASI harus bersifat mencukupi, yang artinya makanan tersebut harus diberikan dalam jumlah, frekuensi, konsistensi dan menggunakan bermacam makanan untuk memenuhi kebutuhan nutrisi bagi pertumbuhan anak dengan masih memperhatikan keberlangsungan pemberian ASI (WHO 2014).

Kebutuhan kalori yang merupakan bagian dari nutrisi harian bayi dapat diketahui dengan perhitungan berdasar rumus hasil penelitian medis. Ini digunakan untuk melakukan aktivitas harian bayi (Heimburger 2006). Kebutuhan kalori tersebut terpenuhi dengan konsumsi makanan atau minuman setiap harinya. Kalori pada makanan yang paling besar dihasilkan oleh kandungan karbohidrat, protein dan lemak dalam setiap bahan makanan (Youdim 2013). Jumlah kalori setiap menu makanan yang akan disajikan juga dapat dihitung berdasar tabel Daftar Komposisi Bahan Makanan (DKBM) yang dikeluarkan oleh Departemen Kesehatan Republik Indonesia (Slamet dan Tarwotjo 1980). Namun, untuk menghitung kebutuhan kalori harian bayi dan menyesuaikannya dengan menu makanan membutuhkan waktu dan kecermatan ibu.

Jika setiap kali ibu menyajikan menu makanan baru bagi bayinya harus melakukan perhitungan kalori, maka akan sangat tidak efektif dan efisien. Selain itu, bagi ibu yang kurang memiliki waktu untuk berkreasi membuat menu makanan baru, dan memilih mencari resep yang ada di buku resep maupun di internet, tidak mendapat cukup informasi terkait kandungan kalori setiap resep, dan belum tentu kandungan kalorinya sesuai dengan kebutuhan kalori bayi. Maka diperlukan sebuah sistem yang dapat merekomendasikan resep MPASI yang sesuai dengan kebutuhan kalori bayi. Sistem rekomendasi merupakan perangkat lunak serta teknik menyediakan saran untuk item-item yang akan digunakan seorang user, yang utamanya ditujukan bagi individu yang kurang berpengalaman untuk mengevaluasi banyaknya jumlah alternatif item yang ditawarkan. (Ricci et al. 2011)

Penelitian terkait sistem rekomendasi resep makanan telah dilakukan oleh Mikami (2014) memperhatikan beberapa faktor dalam menentukan rekomendasi resep makanan yaitu keseimbangan kandungan protein, lemak dan karbohidrat dalam setiap bahan makanan. Penelitian lain oleh Fitri (2013) yang merekomendasikan makanan berdasarkan kebutuhan kalori harian bayi yang telah dihitung dan disesuaikan dengan kalori total dari setiap resep makanan. Dalam merekomendasikan alternatif resep menu yang paling mendekati kebutuhan terkait pola diet, Chien dkk (2011) menggunakan metode fuzzy technique for order preference by similarity to ideal solution(TOPSIS). Fuzzy dalam metode tersebut digunakan untuk mengubah variabel linguistik ke dalam bentuk numerik. TOPSIS dipilih karena dapat mengevaluasi solusi terbaik dengan nilai tertinggi dari indeks persamaan dan cocok digunakan untuk merekomendasikan resep makanan.

Sesuai penelitian yang dilakukan Chien dkk, dalam penelitian ini akan digunakan metode TOPSIS untuk menentukan pilihan/alternatif yang paling mendekati kebutuhan. Sebelum itu, dilakukan filtering terlebih dahulu berdasar masukan dari pengguna terkait usia, berat badan, makanan kesukaan/ketersediaan bahan (like) dan makanan yang tidak disukai/alergi/dihindari (dislike). Kemudian dibuat kombinasi menu yang terdiri dari makanan utama pagi, siang dan malam, juga kudapan diantara waktu makan utama. Dari kombinasi yang dibuat tersebut akan ditentukan mana yang paling mendekati kebutuhan berdasar kandungan protein, lemak dan karbohidrat. 
Hasil dari sistem rekomendasi adalah sajian menu harian dilengkapi resep dan keterangan kandungan kalori yang terdiri dari menu sarapan, makan siang, dan makan malam, juga makanan ringan(snack) diantara waktu makan utama.

\section{METODE}

\section{Batasan Masalah}

Batasan masalah dalam penelitian ini didasarkan atas asumsi-asumsi yang dibuat oleh penulis terkait dengan aplikasi yang dikembangkan dalam penelitian ini. Asumsi yang pertama adalah sistem rekomendasi ini hanya digunakan oleh bayi yang sehat dan tidak memiliki masalah dengan status gizinya. Asumsi yang kedua adalah ASI yang diproduksi oleh seorang ibu sesuai dengan nilai rata-rata yang ditetapkan oleh WHO/Unicef dalam Tabel 1. Asumsi yang ketiga adalah tidak semua ibu memiliki smartphone, sehingga sistem diimplementasikan web based, sehingga dapat diakses dengan browser pada PC ataupun smartphone.

Tabel 1 Energi Rata-Rata yang Diperoleh dari Asupan ASI (WHO/Unicef, 2008)

\begin{tabular}{cc}
\hline Usia & Energi \\
\hline 6-8 bulan & $413 \mathrm{kkal} / \mathrm{hari}$ \\
$9-11$ bulan & $379 \mathrm{kkal} / \mathrm{hari}$ \\
$12-24$ bulan & $346 \mathrm{kkal} / \mathrm{hari}$ \\
\hline
\end{tabular}

\section{Tahapan Penelitian}

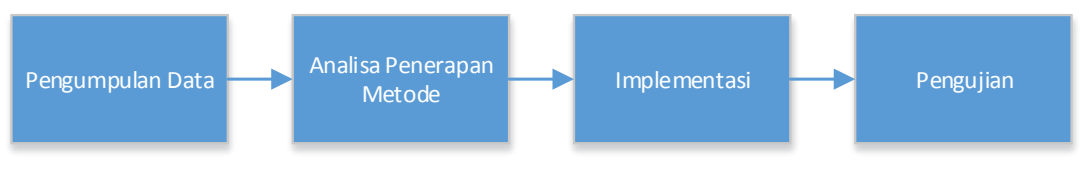

Gambar 1 Alur Penelitian

Dalam penelitian ini, menerapkan seperti pada Gambar 1. Tahap pertama adalah Pengumpulan Data, yaitu melakukan pengumpulan data terkait resep yang akan digunakan dalam rekomendasi, dan Daftar Komposisi Bahan Makanan (DKBM) yang digunakan dalam menghitung nilai nutrisi resep. Tahap kedua adalah analisa penerapan metode, yaitu melakukan analisa bagaimana menerapkan penentuan kebutuhan nutrisi serta pemilihan menu dengan menggunakan TOPSIS. Tahap ketiga adalah implementasi yaitu menuliskan dalam bentuk source code hasil dari tahap kedua menggunakan bahasa pemrograman PHP dan membuat basisdatanya menggunakan MySQL, sehingga menjadi sebuah sistem. Tahap keempat adalah pengujian, yaitu bertujuan memastikan bahwa sistem rekomendasi yang dibuat pada tahap ketiga telah sesuai dengan fungsi yang diharapkan ada dalam sistem.

\section{Alur Kerja Sistem}

Alur dari kerja sistem dapat dilihat pada Gambar 2. Data user yang menjadi input dari sistem rekomendasi ini terdiri dari usia, berat badan, bahan makanan yang dikehendaki ada dalam resep (like), dan bahan makanan yang tidak dikehendaki ada dalam resep (dislike). Sedangkan yang menjadi output dari penelitian ini adalah rekomendasi menu harian bayi yaitu berupa resep-resep MPASI, dimana jumlah resep yang diberikan menyesuaikan dengan jumlah waktu makan berdasarkan usia bayi. Proses-proses yang ada dalam sistem sesuai dengan urutan pemrosesannya yaitu melakukan perhitungan kalori harian bayi, kemudian 
melakukan filtering resep MPASI yang ada dalam database berdasarkan input user dan kebutuhan kebutuhan kalori bayi. Selanjutnya dari resep-resep yang terpilih tadi akan direkomendasikan satu yang paling sesuai untuk bayi menggunakan metode TOPSIS.

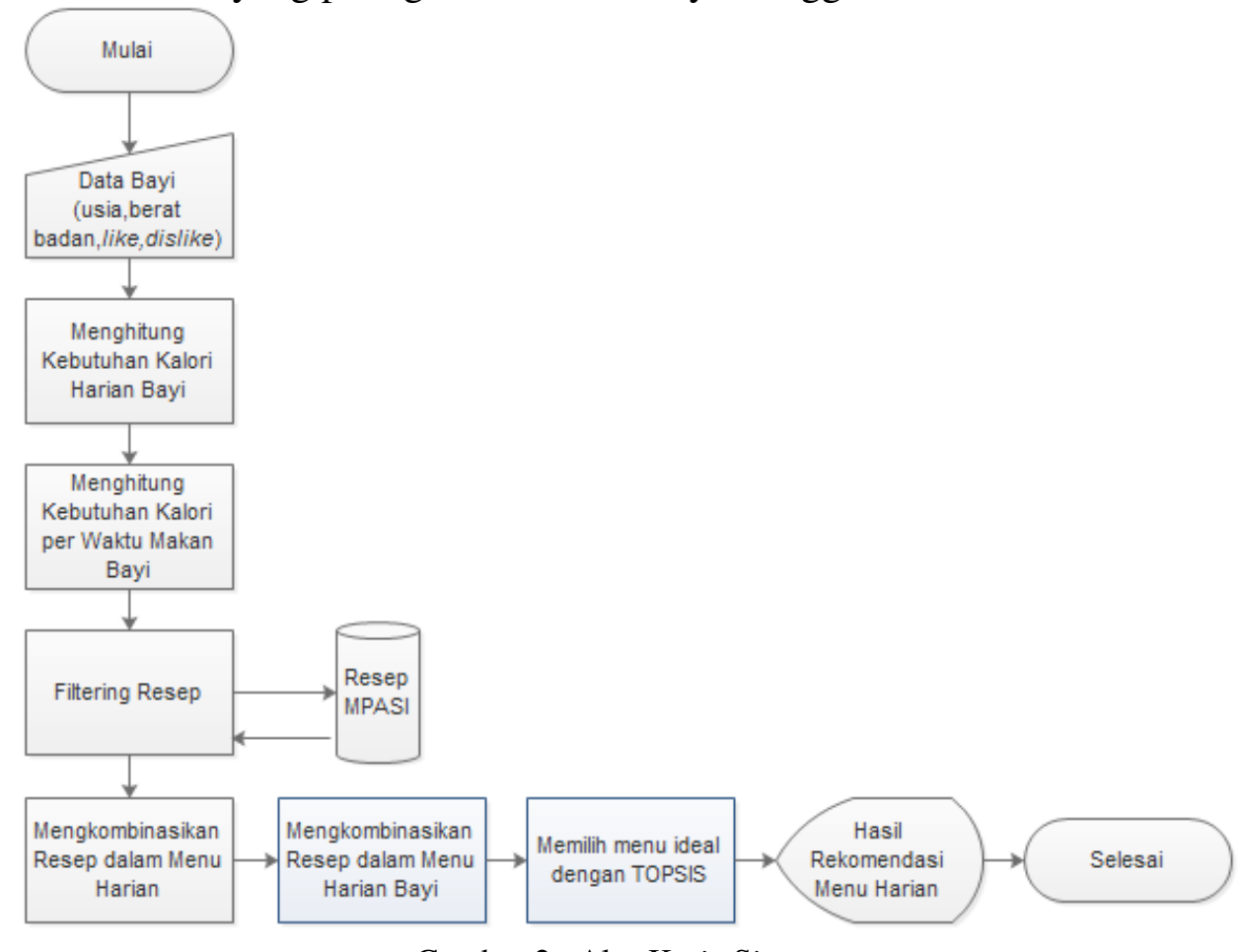

Gambar 2 Alur Kerja Sistem

\section{Perhitungan Kebutuhan Kalori Harian Bayi}

Sebelum menentukan menu, perlu ditentukan terlebih dahulu kebutuhan asupan energi bayi secara total, baik yang berasal dari ASI maupun dari MPASI. Kebutuhan asupan energi dimaksudkan untuk memelihara kesehatan, mencapai pertumbuhan dan kedewasaan yang optimal, dan mendukung level aktivitas fisik yang diinginkan. Persamaan untuk menentukan kebutuhan energi disebutkan dalam dietary reference intakes (DRIs) sebagai estimated energy requirement (EER) (Heimburger 2006), dimana penentuan nilainya dapat dilihat pada Tabel 2.

Tabel 2 Persamaan Penetuan Kebutuhan Energi (Heimburger 2006)

\begin{tabular}{rc}
\hline \multicolumn{1}{c}{ Usia } & Nilai EER \\
\hline 6 bulan & $(89 \times$ berat badan $[\mathrm{kg}]-100)+56(\mathrm{kcal}$ energy deposition $)$ \\
$7-12$ bulan & $(89 \times$ berat badan $[\mathrm{kg}]-100)+22(\mathrm{kcal}$ energy deposition $)$ \\
$13-24$ bulan & $(89 \times$ berat badan $[\mathrm{kg}]-100)+20(\mathrm{kcal}$ energy deposition $)$ \\
\hline
\end{tabular}

Nilai EER yang diperoleh dari Tabel 2 merupakan nilai dari kebutuhan total energi bayi, yaitu yang berasal dari ASI maupun MPASI. Oleh karena itu, dalam sistem rekomendasi ini nilai EER perlu dikurangi dengan energi yang diperoleh dari asupan ASI, sehingga dapat diketahui kebutuhan energi dari asupan MPASI. Kebutuhan energi dari asupan MPASI inilah yang nantinya menjadi dasar untuk merekomendasikan menu.

Dalam penelitian ini, digunakan asumsi dasar bahwa secara umum energi yang diperoleh seorang bayi dari ASI ibunya sesuai dengan usia bayi sama dengan hasil penelitian WHO di negara berkembang(Tabel 1). Asumsi ini dilakukan dengan pertimbangan akan sulitnya seorang ibu jika dalam menggunakan aplikasi ini harus mengukur jumlah kalori harian rata-rata yang dikandung dalam ASI-nya untuk setiap pergantian bulan usia bayinya. 


\section{Menghitung Kebutuhan Kalori Per Waktu Makan Bayi}

Pemberian MPASI, merupakan proses bagi bayi dalam belajar makan seperti layaknya orang dewasa (baik jumlah maupun tekstur). Oleh karena itulah, jumlah waktu makan (pemberian) MPASI tidaklah sama untuk setiap usia (Tabel 3).

Tabel 3 Jumlah Waktu Pemberian MPASI Per Hari (WHO 2014)

\begin{tabular}{rcc}
\hline \multicolumn{1}{c}{ Usia } & $\begin{array}{c}\text { Jumlah } \\
\text { Waktu Makan Utama }\end{array}$ & $\begin{array}{c}\text { Jumlah } \\
\text { Waktu Makan Snack }\end{array}$ \\
\hline 6 bulan & 2 & 0 \\
$7-8$ bulan & 3 & 0 \\
$9-11$ bulan & 3 & 1 \\
$12-24$ bulan & 3 & 2 \\
\hline
\end{tabular}

Dalam penelitian ini diasumsikan makan pagi memenuhi kecukupan kalori $\pm 25 \%$ dari total kebutuhan kalori harian, snack antara makan pagi dan siang memenuhi kecukupan kalori $\pm 10 \%$ dari total kebutuhan kalori harian, makan siang memenuhi kecukupan kalori $\pm 30 \%$ dari total kebutuhan kalori harian, snack antara makan siang dan malam memenuhi kecukupan kalori $\pm 10 \%$ dari total kebutuhan kalori harian, makan malam memenuhi kecukupan kalori \pm 25\% dari total kebutuhan kalori harian (Pardede 2014).

\section{Filtering Resep Berdasarkan Kebutuhan Kalori}

Dalam penelitian ini, digunakan toleransi sebesar $\pm 20 \%$ dari total kebutuhan kalori harian bayi, untuk setiap waktu makan bayi. Resep-resep yang memenuhi kebutuhan batas kalori untuk setiap waktu makan bayi, maka akan terpilih menjadi kandidat resep dalam menu yang direkomendasikan.

\section{Pengkombinasian Resep dalam Menu Harian Bayi}

Semua resep yang terpilih untuk setiap jenis waktu makan, kemudian dikombinasikan satu sama lain untuk menjadi alternatif menu harian bagi bayi. Selanjutnya alternatif-alternatif menu tersebut akan dipilih yang paling sesuai dengan kebutuhan bayi.

\section{Pemilihan Menu Ideal Menggunakan TOPSIS}

Kriteria pertimbangan dalam pemilihan beberapa alternatif menu menjadi menu yang direkomendasikan adalah kecukupan energi dari karbohidrat, protein dan lemak. American Academy of Pediatrics menyarankan untuk bayi sehat, kecukupan karbohidrat harus mencakup 35\% sampai 65\% dari asupan energi total, lemak sebanyak 30\% sampai 55\% dari asupan energi total, dan protein sebanyak $7 \%$ sampai $16 \%$ dari asupan energi total (Heimburger 2006). Oleh karena itu, seluruh alternatif menu akan dicari yang kandungan energi dari Protein, lemak, dan karbohidratnya mendekati nilai yang paling ideal.

Untuk menentukan alternatif menu yang kandungan energinya mendekati ideal (optimal), digunakan metode TOPSIS untuk menentukan mana yang paling ideal. TOPSIS merupakan metode yang membandingkan sekumpulan alternatif dengan mengidentifikasi bobot setiap kriteria, menormalisasi nilai setiap kriteria dan menghitung jarak geometris antara setiap alternatif dan alternatif ideal, yang merupakan nilai terbaik dalam setiap kriteria. Metode TOPSIS didasarkan pada konsep bahwa alternatif terpilih yang terbaik tidak hanya memiliki jarak terpendek dari solusi ideal positif tetapi juga memiliki jarak terpanjang dari solusi ideal negatif (Hwang dan Yoon 1981).

Tahapan dalam metode TOPSIS adalah sebagai berikut:

1) Menentukan alternatif pilihan $(A)$ yang akan direkomendasikan dan kriteria $(C)$ yang digunakan untuk mempertimbangkan alternatif pilihan oleh pembuat keputusan.

2) Menentukan bobot dari setiap kriteria oleh pembuat keputusan $(W)$ 
3) Membuat matriks keputusan yang ternormalisasi (rij) untuk setiap alternatif $i(A i)$ dan kriteria $j(C j)$

$$
r_{i j}=\frac{x_{i j}}{\sqrt{\sum_{i=1}^{m} x_{i j}^{2}}}
$$

dengan $i=1,2, \ldots . m$; dan $j=1,2, \ldots . n$;

$x i j=$ nilai skala oleh pembuat keputusan untuk setiap alternatif $i$ pada kriteria $j$

4) Membuat matriks keputusan yang ternormalisasi terbobot $(Y i j)$

dengan $i=1,2, \ldots . m$; dan $j=1,2, \ldots . n$;

$$
Y_{i j}=X_{i j} \cdot W_{i}
$$

5) Menentukan matriks solusi ideal positif $\left(A^{+}\right)$dan matriks solusi ideal negatif $\left(A^{-}\right)$

$$
\begin{aligned}
& A^{+}=\left\{Y_{1}{ }^{+}, \ldots, Y_{n}{ }^{+}\right\} \\
& A^{-}=\left\{Y_{1}{ }^{-}, \ldots, Y_{n}{ }^{-}\right\}
\end{aligned}
$$

$Y j+$ adalah $\max Y i j$ jika $j$ adalah atribut keuntungan; min $Y i j$ jika $j$ adalah atribut biaya.

$Y j-$ adalah min $Y i j$ jika $j$ adalah atribut keuntungan; $\max Y i j$ jika $j$ adalah atribut biaya.

6) Menentukan jarak antara nilai setiap alternatif $i(A i)$ dengan matriks solusi ideal positif $\left(D i^{+}\right)$dan negatif $\left(D i^{-}\right)$

dengan $i=1,2, \ldots m$.

$$
\begin{aligned}
& {D_{i}^{+}}^{+}=\sqrt{\sum_{j=1}^{n}\left(Y_{i}^{+}-Y_{i j}\right)^{2}} \\
& {D_{i}^{+}}^{+}=\sqrt{\sum_{j=1}^{n}\left(Y_{i j}-Y_{i}^{-}\right)^{2}}
\end{aligned}
$$

7) Menentukan nilai preferensi untuk setiap alternatif $i(V i)$

dengan $i=1,2, \ldots m$.

$$
V_{i}=\frac{D_{i}^{-}}{D_{i}^{-}+D_{i}^{+}}
$$

\section{HASIL DAN PEMBAHASAN}

\section{Data Resep MPASI}

Data resep MPASI yang ada dalam sistem ini diperoleh oleh penulis dari berbagai sumber baik buku terkait resep MPASI maupun dari internet, seperti www.ayahbunda.co.id. Jumlah kalori total resep/saji, jumlah kalori dari Karbohidrat, Lemak dan Protein, didapat dari sumber data resep, maupun dengan melakukan perhitungan manual terhadap seluruh komposisi bahan yang ada dalam resep berdasar tabel Daftar Komposisi Bahan Makanan (DKBM) yang dikeluarkan Departemen Kesehatan Republik Indonesia. Nilai total energi resep dihitung dengan menjumlahkan energi dari karbohidrat, lemak dan protein. Setelah data resep lengkap, kemudian data tersebut yang terdiri dari nama, bahan, cara olah, maupun kandungan kalorinya dimasukkan dalam database. Pada saat penelitian ini dilakukan, data resep yang ada dalam basisdata dan yang telah dihitung nilai nutrisinya berjumlah 180 records.

\section{Analisa Penerapan Metode dan Hasil Implementasi Sistem}

Pada saat menggunakan fitur utama dari sistem rekomendasi MPASI berdasarkan nutrisi ini, seorang user akan disajikan halaman Masukkan Data(Gambar 3) yang akan digunakan sebagai input dalam melakukan perekomendasian. Data yang harus diisi pada halaman ini adalah usia dan berat badan bayi, karena merupakan komponen utama dalam penentuan asupan nutrisi bayi dan penentuan resep. Sedangkan bahan yang dikehendaki dan tidak dikehendaki pada makan utama maupun snack bersifat optional karena digunakan hanya untuk memfilter resep agar sesuai preferensi user sebelum dimasukkan dalam menu harian. 


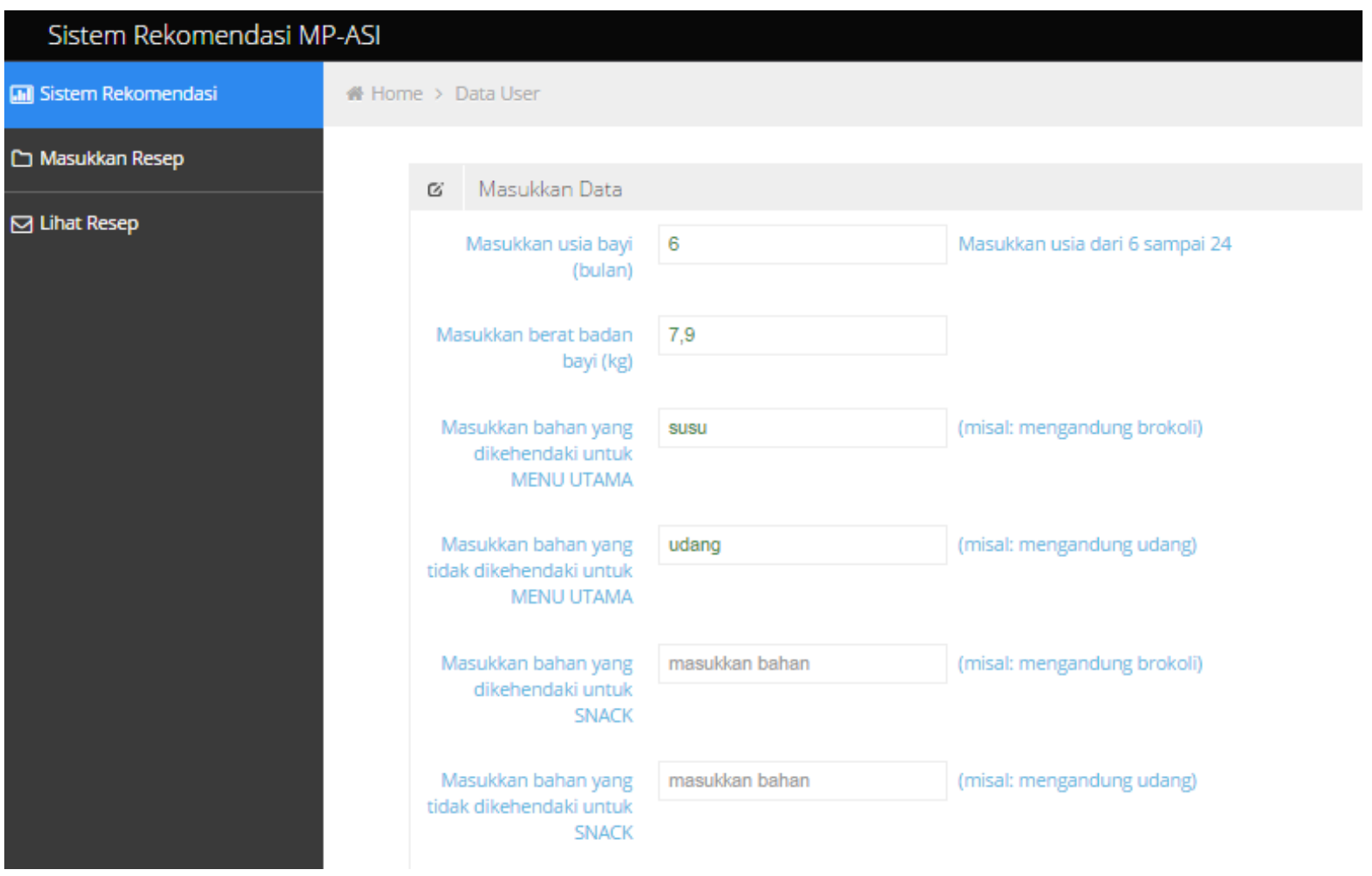

Gambar 3 Halaman Masukan Data Input Rekomendasi

Data input berupa usia dan berat badan kemudian digunakan untuk menentukan EER, dimana nilai EER dikurangi asupan ASI rata-rata akan menjadi kebutuhan kalori harian total dari MPASI. Selanjutnya, data input berupa usia bayi digunakan untuk menentukan jumlah waktu makan bayi, serta kebutuhan kalorinya untuk setiap waktu makan.Kemudian dihitung nilai minimun $(-20 \%)$ dan nilai maksimum $(+20 \%)$ dari kebutuhan harian energi bayi secara total maupun per waktu makan. Hasil dari proses ini terhadap input dari Gambar 3, dapat dilihat pada Tabel 4

Tabel 4 Hasil Perhitungan Kalori Min dan Maks untuk Kebutuhan Energi Total dan Setiap Waktu Makan Bayi

\begin{tabular}{|c|c|c|c|c|c|c|c|c|c|}
\hline \multirow[b]{2}{*}{$\begin{array}{c}\text { Usia } \\
\text { (bulant) }\end{array}$} & \multirow{2}{*}{$\begin{array}{c}\mathrm{BB} \\
(\mathrm{Kg})\end{array}$} & \multirow{2}{*}{$\begin{array}{c}\text { EER } \\
\text { (KKal) }\end{array}$} & \multirow{2}{*}{$\begin{array}{c}\text { Keb } \\
\text { (KKal) }\end{array}$} & \multirow{2}{*}{$\begin{array}{c}\text { Keb } \\
\text { Min } \\
\text { (KKal) }\end{array}$} & \multirow{2}{*}{$\begin{array}{c}\text { Keb } \\
\text { Maks } \\
\text { (KKal) }\end{array}$} & \multicolumn{2}{|c|}{ Makan I } & \multicolumn{2}{|c|}{ Makan III } \\
\hline & & & & & & $\begin{array}{c}\text { Min } \\
(\mathrm{KKal})\end{array}$ & $\begin{array}{c}\text { Maks } \\
\text { (KKal) }\end{array}$ & $\begin{array}{c}\text { Maks } \\
\text { (KKal) }\end{array}$ & $\begin{array}{c}\text { Min } \\
(\mathrm{KKal})\end{array}$ \\
\hline 6 & 7,9 & 659,1 & 246,1 & 196,88 & 295,32 & 90.45 & 108.54 & 0 & 90.45 \\
\hline
\end{tabular}

Setelah diperoleh kebutuhan energi bayi, maka akan dilakukan filtering resep berdasarkan usia bayi (mandatory/harus dilakukan) dan berdasarkan bahan yang disukai maupun yang tidak disukai. Sebagai contoh untuk input pada Gambar 3 akan diperoleh hasil filtering data resep di database seperti pada Tabel 5.

Tabel 5 Hasil Filtering Resep

\begin{tabular}{clcccc}
\hline Kode Resep & Nama Resep & Protein & Lemak & Karbohidrat & Kalori \\
\hline 26 & Bubur Susu Beras Merah & 20.6 & 37.35 & 184 & 241.95 \\
27 & Bubur Susu Roti & 36.4 & 17.1 & 195.16 & 248.66 \\
34 & Bubur Susu Kacang Hijau & 48.6 & 67.5 & 147.4 & 263.5 \\
41 & Bubur Susu Putih & 22.4 & 52.2 & 203.2 & 277.8 \\
\hline
\end{tabular}


Langkah selanjutnya adalah menentukan kombinasi resep untuk menu harian. Pada contoh ini, bayi yang akan direkomendasikan MPASI-nya berusia 6 bulan, sehingga jumlah waktu makannya hanya dua kali dan resep yang digunakan masih sama untuk dua kali waktu makan tersebut. Oleh karena itu, pengkombinasian resep untuk contoh ini, sudah dianggap selesai dan diperoleh alternatif menu.

Setelah memperoleh alternatif menu harian, maka akan dilakukan proses penentuan rekomendasi menggunakan TOPSIS. Bobot yang digunakan dalam perhitungan TOPSIS menggunakan nilai tengah prosentase kecukupan gizi dari Heimburger (2006), yaitu Karbohidrat 50\%, Lemak 42,5\% dan Protein 11,5\%. Output dari perhitungan TOPSIS adalah nilai preferensi untuk setiap alternatif, yang dapat dilihat pada Tabel 6. Semakin tinggi nilai preferensi, maka akan semakin diprioritaskan untuk direkomendasikan.

Tabel 6 Nilai Preferensi Untuk Setiap Alternatif

\begin{tabular}{cccr}
\hline Kode Resep & D+ & D- & V \\
\hline 34 & 17.38637 & 75.05553 & 0.811921 \\
41 & 75.05553 & 75.05553 & 0.500000 \\
26 & 75.05553 & 75.05553 & 0.500000 \\
27 & 75.05553 & 75.05553 & 0.500000 \\
\hline
\end{tabular}

Berdasarkan hasil perhitungan TOPSIS tersebut, maka akan ditampilkan halaman web yang berisi hasil rekomendasi seperti pada Gambar 4

Gambar 4, dimana jika nama resep di klik akan menampilkan halaman Lihat Resep seperti pada Gambar 5. Dikarenakan input usia yang diberikan adalah untuk usia enam bulan, maka menu yang direkomendasikan Gambar 4 hanya satu untuk dua kali waktu makan. Apabila sistem merekomendasikan untuk bayi usia lebih dari enam bulan, maka waktu makannya sudah lebih banyak, sehingga rekomendasi yang diberikan dalam menu hariannya akan lebih banyak seperti pada Gambar 6.

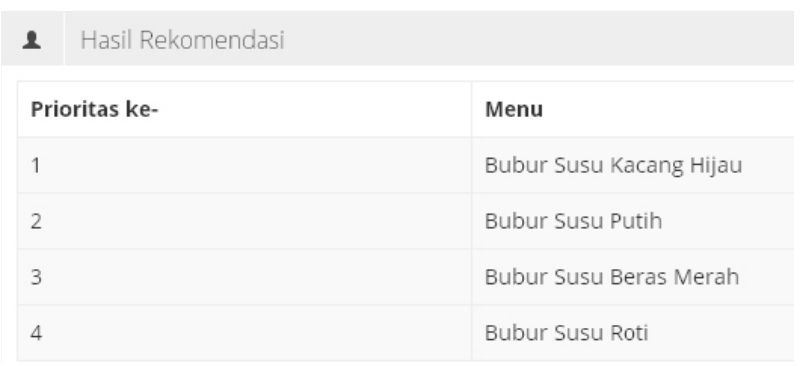

Gambar 4 Halaman Hasil Rekomendasi

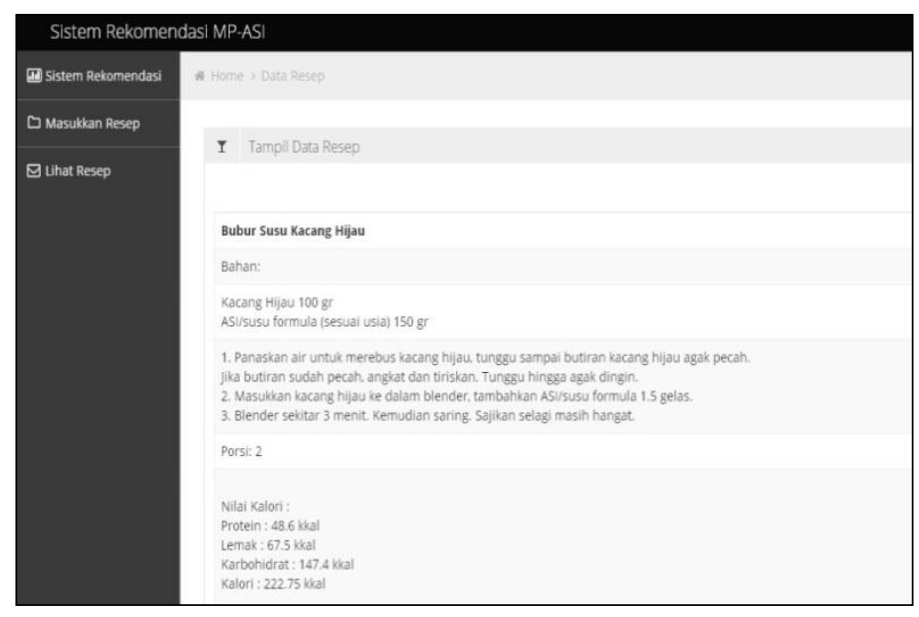




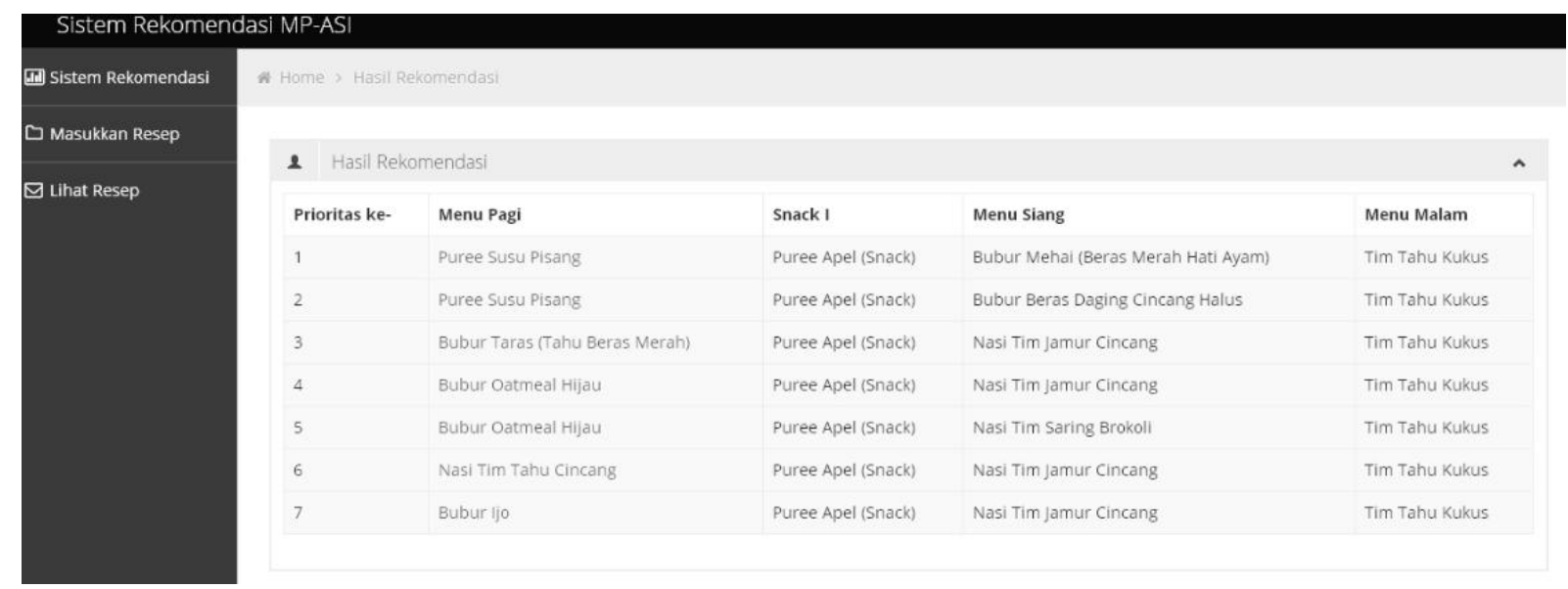

Gambar 6 Halaman Hasil Rekomendasi MPASI Bayi Usia 10 Bulan

\section{Pengujian}

Untuk memastikan bahwa sistem telah berjalan sesuai dengan yang diharapkan, maka dilakukan pengujian dengan beberapa skenario pengujian untuk memastikan setiap fungsi berjalan sesuai dengan yang diharapkan. Fungsi-fungsi yang diujikan beserta hasil dari pengujiannya dapat dilihat pada Tabel 7Tabel .

Tabel 7 Fungsi yang diujikan dan Hasil Pengujiannya

\begin{tabular}{lc}
\hline \multicolumn{1}{c}{ Fungsi } & Hasil \\
\hline Makanan yang direkomendasikan mengandung bahan sesuai preferensi user & Sesuai \\
Resep yang direkomendasikan sesuai usia dan berat badan bayi & Sesuai \\
Jumlah nutrisi dari makanan yang direkomendasikan sesuai energi yang & Sesuai \\
dibutuhkan bayi & \\
$\begin{array}{l}\text { Jumlah waktu makan yang direkomendasikan sesuai dengan usia bayi (khusus 6 } \\
\text { bulan terdapat 2 waktu makan dengan 1 menu) }\end{array}$ & Sesuai \\
$\begin{array}{l}\text { Rekomendasi menu yang diberikan memiliki nilai nutrisi yang paling mendekati } \\
\text { kebutuhan energi bayi daripada alternatif menu yang lainnya }\end{array}$ & Sesuai \\
\hline
\end{tabular}

\section{SIMPULAN}

Pada penelitian ini telah dikembangkan sebuah sistem rekomendasi MPASI yang memperhatikan nutrisi bayi usia 6-24 bulan. Penentuan kebutuhan nutrisi diperoleh dari usia dan berat badan bayi, sehingga kedua data tadi menjadi input penting bagi sistem ini. Sistem ini juga memperhatikan preferensi bayi/ibu terhadap makanan yang dikehendaki ada ataupun dikehendaki tidak ada dalam resep. Untuk penelitin lebih lanjut, dapat dikembangkan perencanaan menu MPASI selama seminggu yang memperhatikan variasi serta proses pembelajaran bayi terhadap makanan. Selain itu, juga dapat dilakukan usability testing terhadap aplikasi yang dibuat untuk melihat pengaruhnya terhadap user.

\section{UCAPAN TERIMA KASIH}

Penulis mengucapkan terimakasih kepada Lembaga Penelitian dan Pengabdian Masyarakat (LPPM) Universitas Negeri Sebelas Maret yang memberikan hibah dana dalam penelitian ini dalam skema Start Up 2014. 


\section{DAFTAR PUSTAKA}

Agostoni, C. et al. 2008. Complementary Feeding: A Commentary by the ESPGHAN Committee on Nutrition. European Society for Pediatric Gastroenterology, Hepatology, and Nutrition.

Chien, Y. H., Li, C. H., Tzuo, M. C., Li, F. C., \& Chao, J. 2011. A Web-Based Decision Support System for Dietary Analysis and Recommendation, 11 (2), 69-75.

Fitri, Setyawati, O., \& Rahadi, D. 2013. Aplikasi Jaringan Syaraf Tiruan untuk Penentuan Status Gizi Balita dan Rekomendasi Menu Makanan yang Dibutuhkan. Electric power, Electronic, Communication, Control Informatics International Seminar, 7 (2), 119-124.

Heimburger, D. C. 2006. Handbook of clinical nutrition. St. Louis: C.V. Mosby Co.

Hwang, C.L. \& Yoon, K. P. 1981. Multiple Attribute Decision Making: Methods and Applications. New York: Springer-Verlag.

Mikami, R., Nakano, H., Dowaki, K., \& Ohwada, H. 2014. A Next-Generation Recipe Recommendation System for Health and Environment. International Journal of eEducation, e-Business, e-Management and e-Learning, 4 (1), 63-66.

Pardede, A. S. 2014. Panduan gizi \& pengaturan menu makanan. SLIDESHARE.net. Diakses 16 Juni 2014. <http://www.slideshare.net/AnitaSriwaty/panduan-gizi>

Ricci, F., Rokach, L., \& Shapira, B. 2011. Recommender System Handbook. New York: Springer Science \& Business Media.

Slamet D.S. \& Tarwotjo I. 1980. Komposisi Zat Gizi Makanan Indonesia. Jurnal Penelitian Gizi dan Makanan, 4, 21-36.

WHO. 2014. "Complementary feeding". WHO.int. Diakses pada 8 Mei 2014. $<$ http://www.who.int/nutrition/topics/complementary_feeding/en/>

Youdim, A. 2013. Nutrition: General Considerations. MERCKMANUALS.com. Diakses pada 8 Juni 2014. <http://www.merckmanuals.com/professional/nutritional_disorde

rs/nutrition_general_considerations/overview_of_nutrition.html> 